\title{
DETERMINANTS OF CHINESE FOREIGN DIRECT INVESTMENT IN CENTRAL AND EASTERN EUROPE
}

Abu Dayeh, B., Janíčko, M.

Barbora Abu Dayeh / University of Economics, Faculty of Economics, Department of Economics, nám. Winstona Churchilla 1938/4, 13067 Praha 3-Žižkov, Czech Republic. Email: barbora@belvoncik.net

Martin Janíčko / University of Economics, Faculty of Economics, Department of Economics, nám. Winstona Churchilla 1938/4, 13067 Praha 3-Žižkov, Czech Republic. Email: martin.janicko@email.cz

\begin{abstract}
The article deals with China's outward direct investment (ODI) in Europe. The ODI has been on the rise and is unique in the sense that its development is much faster than in any other developing country. We investigate the determinants of Chinese ODI in ten countries of Central and Eastern Europe in the time span of 2005 and 2018. Using panel data analysis, the regression model incorporates both traditional macroeconomic variables as well as selected institutional variables, trying to test which of those work best at explaining the Chinese investment activity in the countries of interest. The quality of the institutional framework is represented by EBRD indicators, which seem to be more suitable for transition economies. Findings generally suggest that Chinese multinational enterprises do not access Central and Eastern European countries primarily for market-seeking reasons. However, the fact of being a member of the EU helps Chinese ODI since the membership is used as a sort of "backdoor" to the large European markets. Still, Chinese ODI is less likely associated with a sound institutional environment of a host country, as the opposite appears to be true. These findings, therefore, support the hypothesis that access to the single EU market and R\&D spending are more important determinants of the Chinese ODI than almost any other factors. Implications for Central European audience: The article explores the main drivers of Chinese foreign direct investment in the CEE region while it employs the most relevant theoretical framework, including several recently developed theories. The quantitative analysis then thoroughly explores the weight and sign of selected drivers using recent data and questions some of the conventionally accepted surmises about motivations of Chinese investment activity in the CEE region. This is an important topic given the ongoing debates about China's influence in the region as well as about the intensity and general value added of its investment activity.
\end{abstract}

Keywords: foreign direct investment; China; CEE region; institutional determinants; macroeconomic determinants; panel data

JEL Classification: E22, F21, F23, C23 


\section{Introduction}

It can be considered common knowledge that foreign direct investment (FDI) is a key financial instrument in today's interconnected world and, since current development in technology and communication enables the cross-border exchange to expand rapidly; it also contributes to creating and maintaining stable, long-lasting economic relationships between countries. FDI can be beneficial for both home and host country as the surplus of capital (savings) in one economy can substitute for lack of capital (savings) in another one, and therefore foreign investment often serves as an important source of development.

In 2015 FDI hit the highest level since the global financial crisis in 2008. Although since then the total amount of worldwide FDI has been gradually declining, its importance is expected to further grow in the foreseeable future. In the last decade, China became one of the most important international FDI players in both inward FDI and outward FDI (hereinafter, outward foreign direct investment is referred to as 'ODI'). According to the UNCTAD World Investment Report 20191, China was the second biggest worldwide recipient of FDI as well as the second-largest provider of ODI in 2018. Therefore, China is without a doubt worth studying as its ODI is leading both in the developed and developing world.

Since the new millennium and especially after the financial crisis, Chinese ODI began to flow to Central and Eastern Europe (CEE) in greater volumes as the Eastern part of Europe yields benefits to China when especially appealing is its strategic location and cheap yet qualified labour force (Konzett et al., 2015). Despite the rising importance of the CEE region for the Chinese ODI, economic studies have for the present omitted this area of research and, when executed, results are rather mixed.

This paper focuses on macroeconomic data study of Chinese ODI and its determinants in host countries of the CEE. The main aim is to find out why Chinese firms tend to invest there and what are they mostly attracted by. A regression analysis of both economic and institutional determinants is performed and hopefully sheds more light on this question.

The rest of the article is organized as follows: first, we present theoretical background containing the basics of ODI theory and laying down the most important features of Chinese foreign direct investment as well as discussing some Chinese peculiarities and introducing Chinese ODI in Central and Eastern Europe. Second, the determinants of Chinese ODI in post-communist European countries are studied through a panel regression model analysis using aggregate macroeconomic data. The next section discusses the results. The conclusion summarises key findings.

\section{Outward direct investment and China}

The general principles of the ODI theory were for the first time formulated in the 1970s, mainly by John H. Dunning and Peter J. Buckley. Probably the most famous ODI theory is the eclectic paradigm, or so-called OLI framework, proposed by John H. Dunning in 1977. It explains the decision-making of multinationals or MNEs when choosing ODI to enter international markets instead of choosing other methods like licensing or product exports. For

\footnotetext{
1 Data from UNCTAD correspond with the main source of Chinese ODI data, i.e. the Annual Statistical Bulletin on China's Outward Foreign Direct Investment published by Chinese Ministry of Commerce (MOFCOM), co-published with the State Administration of Foreign Exchange (SAFE) and the National Bureau of Statistics (NBS).
} 
an ODI to occur, the firm must possess ownership advantages ('O' in the word OLI), internalization advantages ('I' in the word OLI) and location advantages (' $\mathrm{L}$ ' in the word OLI) from investing abroad.

This paper focuses on the location aspects of investments, and there can be distinguished three main motivations of internationalization of markets related to those: resource-seeking, efficiency-seeking and market-seeking (Dunning \& Narula, 2003). Resource-seeking ODI refers to seeking natural resources in a foreign country as well as for technology or research and development (R\&D) capacity, which is also referred to as technology-seeking or strategic-asset-seeking ODI. Efficiency-seeking ODI corresponds with investments made to lower the costs of production, especially by lower wages in the foreign country. Finally, market-seeking ODI is undertaken for the most traditional reasons, such as accessing distribution networks and enhancing exports from the home country to other markets. Another theory elaborating on the eclectic paradigm but rising from an evolutionary point of view is the investment development path theory first articulated by John Dunning in 1979. The investment development path theory reflects the evolution of domestic firms' competitive advantages on international markets from the first stage, when domestic firms are unable to compete with foreign firms, until the last stage, when domestic firms are already internationalized, having their ownership advantages.

A slightly different approach is followed by a life cycle theory of ODI elaborated by Huang and Wang (2013), who proposed that first, a country's ODI is resource-seeking or, more specifically, technology-seeking. This type of investment was classified as Chinese style investment since developing countries need to seek advanced technologies abroad. Then along with the economic development of the country and rising wages, respectively, ODI becomes efficiency-seeking like Japanese style investment in the 1980s. And finally, together with the globally advanced economy, ODI turns into market-seeking like current American style ODI. Huang and Wang (2013) further propose that this development pattern will also be observed in the case of China as it will gradually change into a U.S.-style investor.

Multiple studies have also focused on differences in the motivation of ODI when investing in a developed or developing country (Amighini et al., 2014; Cheung \& Qian, 2009). They have pointed out that in low-income countries, ODI is mainly made in manufacturing, where it takes advantage of inexpensive skilled labour and usually is undertaken in the form of Gls; however, ODI in high-income countries is realized mostly in business services, sales, marketing and support and it more often takes the form of M\&As.

Meanwhile, the institutional framework can indeed be influential both in attracting or repelling inward FDI as well as either supporting or impeding outward FDI (Voss et al., 2010; Wang et al., 2012; Wang et al., 2015). Dunning and Lundan (2008) incorporated institutions into the already mentioned eclectic paradigm stating that institutions are fundamental to all three components of the OLI framework. Institutions are crucial in connection with location advantages as government policies can either support or repel FDI, and institutional framework such as level of corruption or the rule of law plays a part in the attractiveness of a country. Institutions hence affect the decision-making of firms about undertaking ODI, and they must not be omitted from the general ODI theory.

China's total overseas investment flows hit USD 129.8 billion, and its total ODI stock reached almost 2 trillion USD in 2018, according to UNCTAD World Investment Report 2019. China 
is the second-largest investor globally after Japan, while it has become a leading investor in both the developed and developing world, from which especially in Africa. The figure below shows Chinese ODI flow development since 2000, demonstrating thereby China's rising importance as a worldwide investor.

\section{Figure 1 | Chinese ODI flow between 2000 and 2018}

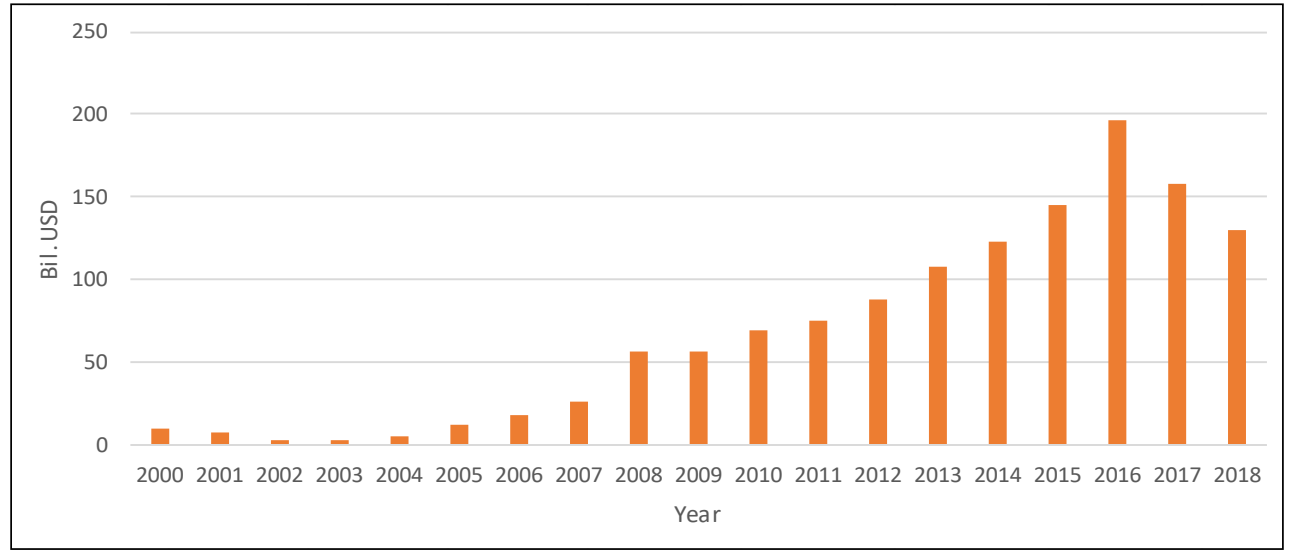

Source: UNCTAD World Investment Report (2019)

Regarding the regional distribution of Chinese ODI, conclusions should be drawn very carefully as there are large discrepancies between measured data and real investments made. BBVA Research Group carried out important research about this issue in 2015, and they identified two main problems connected to Chinese ODI statistics. The first one is offshoring, which means that Chinese firms initially invest in a country with a lower tax rate, or a kind of tax haven, to use its benefits and later invest the same amount of money in a third country. Tax havens most frequently used by China are Hong Kong, the Cayman Islands and the British Virgin Islands. The second problem identified is round-tripping, when Chinese ODI is first channelled to a special purpose vehicle (SPV) in some foreign country in order to subsequently return to China, having all the advantages that China grants to foreign investors (Garcia-Herrero et al., 2015).

Therefore, official ODI data from China are inaccurate and exaggerated. Sutherland and Anderson (2015) identified the problem of biased data as the most important one when executing research on Chinese MNEs, stating that the majority of studies do not deal with it. BBVA Research Group counted that in 2013 40\% of ODI flows to Hong Kong were roundtripped, $30 \%$ continued to third countries, and 30\% stayed in Hong Kong. In the case of the Cayman Islands and the British Virgin Islands, $12 \%$ of ODI flowed further into the world.

With the rising importance of China, many studies emerged in the area of investments though the majority still focusing on Chinese FDI and not on its ODI. The literature does not provide a clear picture of the determinants of Chinese ODI in host countries. It is not obvious whether Chinese ODI is resource-seeking (Cheung \& Qian, 2009; Wang et al., 2012) or whether it is independent of the host country's raw materials endowment, as claimed by Buckley et al. (2007) at least for the period of 1984-1991. Also, it is not clear whether Chinese ODI is truly strategic-asset-seeking, as supported by Cheung and Qian (2009) and Wang et al. (2012) but again opposed by Buckley et al. (2007). Scholars seem to agree that Chinese foreign 
investment is at least partly market-seeking since, in many studies, GDP, as a variable representing market size, was found statistically significant (Cheung \& Qian, 2009; Kolstad \& Wiig, 2012). Newer studies also support the idea that Chinese ODI is promoted by high exports and economic exchange with the host country (Voss et al., 2010; Amighini et al., 2011). Chen and Tang (2014), who studied Chinese ODI from a micro-level point of view, found that Chinese ODI is positively connected to both imports and exports from the host country and that ODI also promotes Chinese exports itself. Therefore, ODI is an important fraction of a country's structural transformation from low-skilled manufacturing to high-skilled services country.

Interestingly, many studies discovered that Chinese ODI is attracted to countries with high political risk (Buckley et al., 2007; Kolstad \& Wiig, 2012; Amighini et al., 2011; Li et al., 2015). Meanwhile, Amighini et al. (2011) provide an explanation that Chinese firms might prefer countries with high corruption because rents from natural resources are more easily obtained there, which also corresponds with Kolstad and Wiig (2012) findings that natural resources are usually coupled with bad institutions, a phenomenon also known as 'resource curse'.

China seems to be, on the one hand, motivated by market-seeking when investing in developed OECD countries (Cheung \& Qian, 2009; Kolstad \& Wiig, 2012), on the other hand, it seems to be resource-seeking in case of developing or non-OECD, countries (Kolstad \& Wiig, 2012). However, the results differ significantly across studies, and especially the connection between Chinese ODI and host country institutional framework is not quite clear yet.

Third world countries do not possess advanced technology. That is why their ODI is determined by the advantages of low-cost production and flexibility. However, China was able to overcome such third-world difficulties by acquiring R\&D hubs in advanced economies, and, in connection with low-cost production at home, Chinese MNEs had suddenly gained a competitive advantage on international markets (Hong \& Sun, 2006). Lu et al. (2011) propose that Chinese firms have a good position in international markets due to huge rivalry in the Chinese market; hence only very strong and aggressive firms survive the domestic competition.

Besides acquiring R\&D capacities abroad and thereby counterweighting their disadvantages of a developing country, Chinese MNEs have other specificities that help them internationalize quickly and effectively and that are unique to the Chinese environment. Buckley et al. (2007) mentioned three main arguments supporting the idea that China is different, and so the ODI theory is applicable to it.

First, China possesses several capital market imperfections that can be turned into firms' ownership advantages. By capital market imperfections, Buckley et al. (2007) mean availability of capital at below-market rates. The most important capital market imperfection is state ownership of many MNEs because such companies obtain a lot of government support when investing overseas. Wang et al. (2012) even classified the fact of being an SOE as 'home-cultivated firm-specific advantage'. Because of deep governmental involvement, SOEs are not purely profit-maximizing, but their behaviour is driven by political objectives, too (Kolstad \& Wiig, 2012). China provides cheap capital to domestic firms also via an inefficient banking system as the largest banks and the biggest investment corporations, such as China International Trust and Investment Corporation (CITIC) or sovereign wealth fund 
China Investment Corporation (CIC), are state-owned. Those investment corporations support many Chinese MNEs through enormous foreign exchange reserves stock accumulated by the Chinese government in the last decades (Konzett et al., 2015). Because of immense support from the government, Chinese SOEs are unable to assess foreign risk profoundly, and that may also be the reason why they invest in riskier markets (Voss et al., 2010).

Further, Chinese firms hold special ownership advantages that allow them to invest in other developing countries with better results than are those of their western counterparts. That is because Chinese MNEs are used to poor institutional environment and high corruption (Kolstad \& Wiig, 2012). In addition to that, Chinese firms are very skilled in social networking, thanks to the Chinese culture of 'relationships' (关系 guanxi). Such relational assets provide them with smooth market information flow about the most profitable investments available. Therefore, the existence of Chinese diaspora in a host country is an important fact that increases the attractiveness of such a country.

Third, domestic institutions are crucial factors that determine the willingness of Chinese firms to invest overseas. Government supportive policies surely boost Chinese ODI mainly by already mentioned low-cost capital but also by other means like privileged access to natural resources or subsidies. However, capital in China is still strictly watched, especially after the rapid rise in its outflow and unexpected devaluation of the Chinese yuan (RMB) in August 2015, and it is not easy to export it abroad, and that is why the whole approval or registration procedure of ODI is administratively burdensome (Garcia-Herrero et al., 2015).

Having mentioned principal specialities of the Chinese environment, China is a hybrid of a traditional centrally planned system and a market-oriented economy that probably is unique in the whole world. When using all the benefits that the Chinese government provides to domestic firms in connection with still relatively low-cost production, Chinese MNEs, rather than moving their factories abroad, tend to acquire foreign advanced technology by M\&A and JV. Thereby, they try to improve the firm's competitiveness and establish a globally recognized brand name (Huang \& Wang, 2013). Western countries often see China as aggressive and dangerous as they fear losing key technologies, which could also lead to losing their international competitive advantages. Worries about Chinese misuse of high technologies gained by foreign investments due to weak patent protection laws in China are also one of the contributors to the current China-US trade war. Because of this hostility between two global players, Chinese ODI flows in the US has declined and raised in Europe, making Europe the number one recipient of Chinese ODI in 2017 (BBVA Research, 2018).

\section{China and the CEE region}

Since the beginning of the millennium, there is an increasing economic and diplomatic exchange between China and Central and Eastern European countries (CEEC). In the aftermath of the demise of the Soviet Union's, the CEE countries oriented strictly towards the West, and many of them even gained accession to the European Union (EU). However, after the global financial crisis of 2008-2009, CEEC turned their attention towards the East, too, since the EU was in a deep recession, not providing enough funds to its newcomers (Ross, 2016). 
Even though Chinese ODI in CEEC is still insignificant insomuch that in 2018 Chinese ODI flow to CEEC constituted only about $0.4 \%$ of total Chinese ODI flow, the numbers are constantly rising and are gaining their relevance, as also demonstrated by Figure 2, which displays the development of Chinese ODI stock in Central and Eastern Europe since 2005. Trade exchange grew by $30 \%$ per year since the new millennium, and increasing cooperation between China and Eastern Europe resulted in forming 16+1 framework in 2012, which is a platform promoting Chinese investments in the region of 16 European countries: Albania, Bosnia and Herzegovina, Bulgaria, the Czech Republic, Croatia, Estonia, Hungary, Latvia, Lithuania, the FYR Macedonia, Montenegro, Poland, Romania, Serbia, Slovakia and Slovenia (Tianping, 2015). Former Chinese prime minister Wen Jiabao revealed in Budapest in 2011 China's interest in CEEC by stating that 'Eastern Europe is to become China's bridgehead in the EU' (Konzett et al., 2015, p. 2).

\section{Figure 2 | Chinese ODI stock in CEEC 2005-2018}

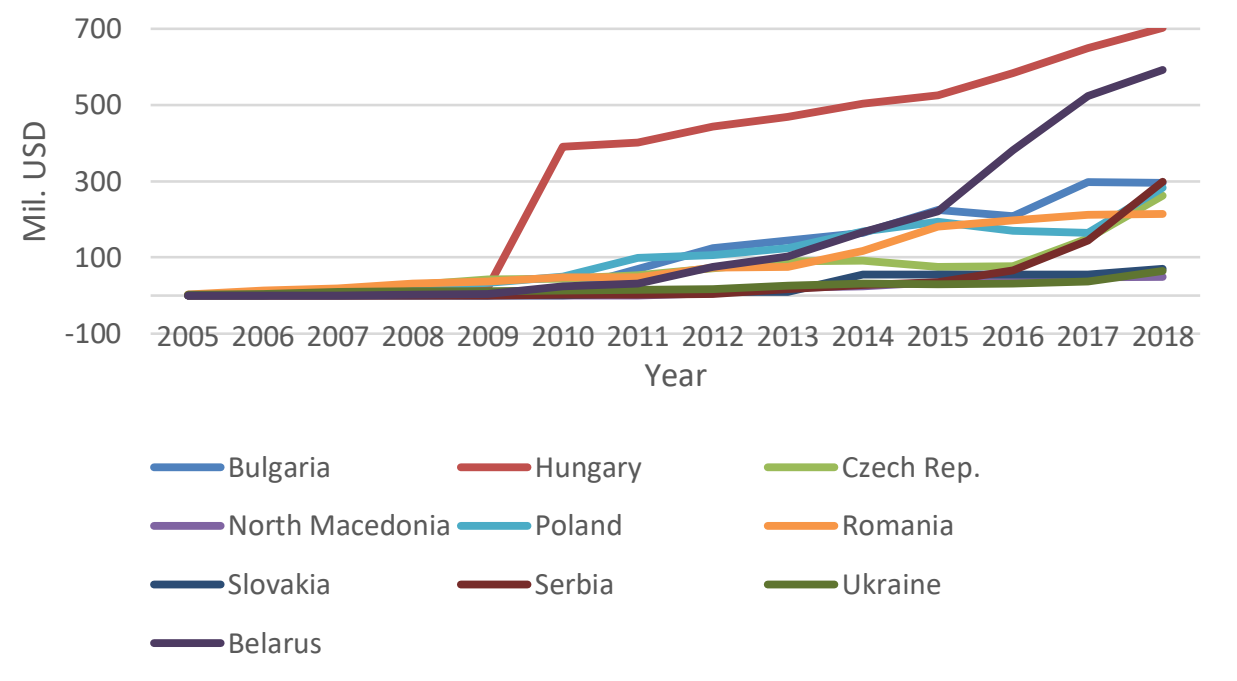

Source: UNCTAD World Investment Report (2019); MOFCOM (2015)

Central Europe attracts Chinese ODI mostly in the form of M\&A, while Balkan states use Chinese money mainly in infrastructure that they urgently need to build. Many projects, especially in South-Eastern Europe (SEE), are financed through the Export-Import Bank of China (Exim Bank), which is under control of the PRC's State Council and which is supposed to promote Chinese exports by also granting loans to foreign states and institutions (Konzett et al., 2015). Infrastructure projects in the SEE are part of the 'Belt and Road' initiative ${ }^{2}$ that should link Rotterdam with Jiangsu province in China and Balkan provides for linkage between the Middle East and Western Europe. Chinese shipping company COSCO entered again into dialogue for acquiring the majority of privatized Greek port Piraeus, and in 2015 a

\footnotetext{
2 The Silk Road Economic Belt and the 21st-Century Maritime Silk Road or the so-called 'Belt and Road' initiative (一带 一路 yidaiyilu), which was recently launched by the president Xi Jinping, should promote sustainable growth of Chinese economy and further encourage investment especially in the field of infrastructure (KPMG, 2016).
} 
Chinese company China Railway Group (CRG), won the contract for building a USD 1.6 billion high-speed railway from Budapest to Belgrade that should further accelerate the supply of Chinese goods to Europe (Goh, 2015).

Therefore, Chinese interests in promoting 'Belt and Road' initiative in CEEC are to enhance its exports to Europe and to obtain advanced western R\&D capacities through the CEEC as the EU backdoor. Not omitting other essential interests like exploitation of natural resources that China lacks as well as diversification of risk, since for now, China is over-dependent on the US, as it holds a massive amount of its debt. Thus its portfolio is not well-diversified, and the peace in Pacific Asia is quite fragile too. China also hopes to enhance its underdeveloped western provinces by connecting them with Central Asia and further Eastern Europe. Hence geopolitical reasons play a role in China's engagement in the CEEC.

The importance of the Belt and Road policy (often overlooked by foreign countries) is proved by the fact that Chinese ODI to members of the Belt and Road initiative is rising faster than to non-members (Du \& Zhang, 2018) and also by the creation of Asian Infrastructure Investment Bank and New Development Bank and by Beijing's statement that it is willing to lend up to USD 8 trillion to infrastructure projects (Bruce-Lockhart, 2017). According to the UNCTAD World Investment Report 2019, Chinese ODI to the Belt and Road countries expanded to $14 \%$ of total Chinese ODI, partly also caused by the worsened relationship with the US. A clear shift in the structure of Chinese ODI from previously supported investments to property, entertainment and sport to investments to commodity and energy sectors (BBVA Research, 2018) also provides a space for Chinese overproduction of steel and heavy equipment as those are mostly used in infrastructure development, which is often done fully or in cooperation with Chinese SOEs (Bruce-Lockhart, 2017).

Economic studies so far rather rarely deal with the Central and Eastern European region, and this region has been rather neglected by scholars. There are several studies focusing on determinants of ODI flowing to these countries, and their results are more or less mixed. Carstensen and Toubal (2003) found out that Central European countries are more successful in their transition than South and East Europe, and CEE attract ODI by the sound legal and economic environment, while SEE benefits from the low-cost educated labour force. Botrić and Škuflić (2006) assert that the openness of the country and overall economic development is the most important factor positively influencing ODI in Balkan countries. Kersan-Škabić (2013) and Donu and Janíčko (2018) focused on institutional determinants of ODI in CEE countries when performing a regression analysis of macroeconomic data, and their results are similarly stating that institutional variables, such as business and investment freedom or a good regulatory framework, are important determinants for attracting ODI, yet by far not crucial. Somewhat less recent research conducted by Korniyenko and Sakatsume (2009) examined Chinese ODI in the EBRD's countries and concluded that driving motives are resource-seeking and market-seeking, with strategic-asset-seeking motivation rising in the last years of the study.

Éltetö and Szunomár (2016) studied the development of Chinese investment and trade in CEEC and confirmed Chinese intent to use the CEEC as a 'back door' to the EU. They also highlight differences between countries as the Czech Republic, Slovakia and Hungary are more developed, and their trade is based on high-tech products, while Poland, Bulgaria and Romania supply China with raw materials and rather low-tech products. However, it seems that CEEC is not fully leveraging the Chinese One Belt One Road initiative as the majority of 
these countries have very low trust in Chinese companies and their objectives, and China so far did not persuade CEEC that the initiative is beneficial for all participating parties (BBVA Research, 2018).

\section{The data and model}

Éltetö and Szunomár (2016) studied the development of Chinese investment and trade in CEEC and confirmed Chinese intent to use the CEEC as a 'back door' to the EU. They also highlight differences between countries as the Czech Republic, Slovakia and Hungary are more developed, and their trade is based on high-tech products, while Poland, Bulgaria and Romania supply China with raw materials and rather low-tech products. However, it seems that CEEC is not fully leveraging the Chinese One Belt One Road initiative as the majority of these countries have very low trust in Chinese companies and their objectives, and China so far did not persuade CEEC that the initiative is beneficial for all participating parties (BBVA Research, 2018).

The data describing Chinese ODI flows to the CEE region have been harvested mainly from the UNCTAD database, where data follow definitions from the MOFCOM database. The data ranges from 2005 until 2018 and has an annual frequency. Chinese data correspond with the OECD Benchmark definition of FDI since 2005, therefore Chinese ODI is computed, accordingly to the OECD's recommendations, on directional principle when recorded on a regional basis, which states that equity, reinvested earnings, and debt instruments are all incorporated in the final FDI statistics. ODI flows are computed as so-called net positions when divestment, or in other words selling off assets or equity, is added in too. Therefore ODI flows can, in certain situations, reach negative values (OECD, 2008). The dataset also contains several negative ODI values and a lot of zero values that cannot be omitted because of their real economic meaning; therefore, in order to further transform them into natural logarithms, some more arrangements needed to be made. All zero and negative values were first put close to zero and consequently transformed into logarithms when such method is commonly used in the case of ODI flows, as supported for example by (Gouel et al., 2012). In this context, the respective threshold for the variable was set at 2 .

Still, it should be noted that both MOFCOM's, and therefore also UNCTAD's data, are likely somewhat underestimated owing to specific reporting practices in China that do not consider all ODI data. However, we believe that this underestimation is unlikely to render the results unreliable.

Since we are dealing with a panel-like dataset, the structure of the data has both the crosssectional and longitudinal part. Specifically, the cross-sectional dimension is represented by the individual countries from the CEE region. Those are the Czech Republic, Slovakia, Hungary, Poland, Serbia, Macedonia, Ukraine, Romania, and Bulgaria. Since data for the ODI is not fully available for all time periods, the panel is essentially unbalanced. Likewise, although it would be desirable to include more variables, we resorted to the model parsimony also because the data quality is, in many cases, very questionable. 
Table 2 | Summary of variables

\begin{tabular}{|c|c|c|c|c|}
\hline Variable & ted & Units & Argument & Source \\
\hline $\begin{array}{l}\text { LODI: annual outflow of } \\
\text { Chinese foreign direct } \\
\text { investment }\end{array}$ & & $\begin{array}{l}\text { Natural logarithm of } \\
\text { USD millions }\end{array}$ & & UNCTAD Database \\
\hline $\begin{array}{l}\text { LGGDP: host country GDP } \\
\text { growth }\end{array}$ & + & $\begin{array}{l}\text { First difference of } \\
\text { natural logarithm of } \\
\text { GDP }\end{array}$ & $\begin{array}{l}\text { market- } \\
\text { seeking }\end{array}$ & World Bank Development Indicator \\
\hline $\begin{array}{l}\text { EU: member state of the EU } \\
\text { (dummy variable) }\end{array}$ & + & $\begin{array}{l}\text { Takes value of } 1 \text { if } \\
\text { EU member and } 0 \text { if } \\
\text { not. }\end{array}$ & $\begin{array}{l}\text { market- } \\
\text { seeking }\end{array}$ & EU Commission \\
\hline $\begin{array}{l}\text { TRADE: ratio of sum of export } \\
\text { and import to host country } \\
\text { GDP }\end{array}$ & + & Ratio. & $\begin{array}{l}\text { market- } \\
\text { seeking }\end{array}$ & World Bank Development Indicator \\
\hline $\begin{array}{l}\text { OREMETAL: ratio of ore and } \\
\text { metal exports to merchandise } \\
\text { exports of host country }\end{array}$ & + & Ratio. & $\begin{array}{l}\text { resource- } \\
\text { seeking }\end{array}$ & World Bank Development Indicator \\
\hline $\begin{array}{l}\text { RD: ratio of host country } \\
\text { expenditures of research and } \\
\text { development to total } \\
\text { expenditures }\end{array}$ & + & Ratio. & $\begin{array}{l}\text { resource- } \\
\text { seeking }\end{array}$ & World Bank Development Indicator \\
\hline $\begin{array}{l}\text { LWAGE: gross average } \\
\text { monthly wage of host country }\end{array}$ & - & $\begin{array}{l}\text { First difference of } \\
\text { natural logarithm of } \\
\text { nominal wage. }\end{array}$ & $\begin{array}{l}\text { efficiency- } \\
\text { seeking }\end{array}$ & UNECE Statistics \\
\hline $\begin{array}{l}\text { PRIVAT: large-scale } \\
\text { privatization index }\end{array}$ & + & $\begin{array}{l}\text { First difference of the } \\
\text { index variable. }\end{array}$ & institutions & EBRD Transition Indicators \\
\hline $\begin{array}{l}\text { ENTRESTRUCT: governance } \\
\text { and enterprise restructuring } \\
\text { index }\end{array}$ & + & $\begin{array}{l}\text { First difference of the } \\
\text { index variable. }\end{array}$ & institutions & EBRD Transition Indicators \\
\hline $\begin{array}{l}\text { TRADEFOREX: trade and } \\
\text { foreign exchange system index }\end{array}$ & + & $\begin{array}{l}\text { First difference of the } \\
\text { index variable. }\end{array}$ & institutions & EBRD Transition Indicators \\
\hline $\begin{array}{l}\text { COMPET: competition policy } \\
\text { index }\end{array}$ & + & $\begin{array}{l}\text { First difference of the } \\
\text { index variable. }\end{array}$ & institutions & EBRD Transition Indicators \\
\hline $\begin{array}{l}\mathrm{CPI} \text { : corruption perception } \\
\text { index }\end{array}$ & $?$ & $\begin{array}{l}\text { First difference of the } \\
\text { index variable. }\end{array}$ & institutions & Amnesty International \\
\hline $\begin{array}{l}\text { POLITICS: countries with } \\
\text { either positive or negative } \\
\text { attitude towards the politics of } \\
\text { the US (dummy variable) }\end{array}$ & - & $\begin{array}{l}\text { Arbitrarily chosen } \\
\text { values based on } \\
\text { affinity towards the } \\
\text { US. }\end{array}$ & $\begin{array}{l}\text { liability of } \\
\text { foreignness }\end{array}$ & Arbitrarily assigned \\
\hline
\end{tabular}

Source: authors' own elaboration 
The following Table 3 presents basic descriptive statistics of the variables in question, excluding the dummy variables.

Table 3 | Descriptive statistics

\begin{tabular}{lcllll}
\hline Variable & Obs & Mean & SD & Min & Max \\
\hline LODI & 139 & 1.67 & 7.81 & -3.51 & 19.73 \\
GGDP & 139 & 3.78 & 2.58 & -14.25 & 21.01 \\
TRADE & 139 & 111.48 & 32.10 & 61.15 & 183.43 \\
OREMETAL & 139 & 5.64 & 4.28 & 1.17 & 18.82 \\
R.D & 139 & 0.75 & 0.41 & 0.17 & 2.00 \\
LWAGE & 139 & 6.64 & 0.37 & 5.31 & 7.25 \\
PRIVAT & 139 & 3.66 & 0.45 & 2.67 & 4.33 \\
ENTRESTRUCT & 139 & 2.92 & 0.61 & 2.00 & 4.33 \\
TRADEFOREX & 139 & 4.44 & 0.17 & 3.30 & 4.33 \\
COMPET & 139 & 3.01 & 0.58 & 1.62 & 4.33 \\
CPI & 139 & 5.75 & 8.10 & 27.00 & 59.20
\end{tabular}

Source: authors' own calculation

The dependent variable ODI and the exogenous variable WAGE are both transformed into natural logarithms as non-linear relationships are expected based on the previous theory. Other macroeconomic variables represent a percentage change over time; therefore, they already are in the form of elasticities; there is no need anymore to transform them into a logarithm. Institutional variables that are in the form of indexes, as well as dummy variables, are not transformed into logarithms either. By taking natural logarithms, the extreme variations in data are mitigated, which further improves the stability of the model.

For robustness reasons, when testing the data, the non-stationarity of certain variables was observed using the Dickey-Fuller test to find the possible presence of a unit root. On the other hand, no cross-sectional dependence was observed using the Pasaran CD test, which may be caused by the fact that the time series studied in this thesis is not that long. Therefore, in order to overcome the problem of non-stationarity, first differences were taken of all the macroeconomic and institutional variables except GGDP, CPI and, obviously, dummy variables, as they did not fail the stationarity test. After adjusting the variables, the stationarity of all data was confirmed. Along with getting rid of stochastic trends, the multicollinearity was reduced in the whole model. Further, Breusch-Godfrey/Wooldridge test proved no serial 
correlation as well as the Breusch- Pagan test rejected the presence of heteroscedasticity in the dataset, so there is no need to use cluster robust standard errors in the regression. ${ }^{3}$

For the purpose of addressing the concern over endogeneity of the macroeconomic variables as well as the quality of institutions since they can affect FDI inflow but also vice versa, all the variables except the dummy ones were one-period lagged, though some observation were thereby lost. Another reason that is behind lagging the variables is the fact that ODI responds more to the previous year's macroeconomic development rather than to the current one, so the lagged model should respond more to reality. This was confirmed by existing research on the topic, e.g. Donu and Janíčko (2018). The multicollinearity was generally low in the model as the highest Variance Inflation Factor reached a maximum of 4 in the case of GDP growth which is still a reasonable value.

In what follows we deploy a model which takes a panel structure by combining the longitudinal and cross-sectional dimension. We decided against pooled OLS approach using F-statistic, Breusch-Pagan Lagrange Multiplier test and Hausman test and selected the Fixed Effects estimator as all three confirmed this is the best choice. This allows us to study the main factors influencing Chinese FDI in the regions of interest as the regular regression does not consider heterogeneity across groups or time.

The FDI data was collected from the UNCTAD database, and it is measured in a million US dollars (at current prices). The independent macroeconomic variables were chosen based on previous literature, suitability for the selected groups of countries and availability of the dataset for the selected period. ${ }^{4}$ The following table depicts the heterogeneity of the OFDI across countries for all 13 periods in our time span. As can be observed, relatively larger OFDIs have been recorded for Bulgaria, Belarus, and Hungary.

\footnotetext{
${ }^{3}$ Unless explicitly reported, and due to the size of the article, most robustness tests can be obtained from the authors upon request.

${ }_{4}^{4}$ It should be noted that we do not distinguish between greenfield and brownfield investment, as this is not permitted by the low data granularity and possible methodological drawbacks of such approach as well as potential problems with hidden endogeneity.
} 


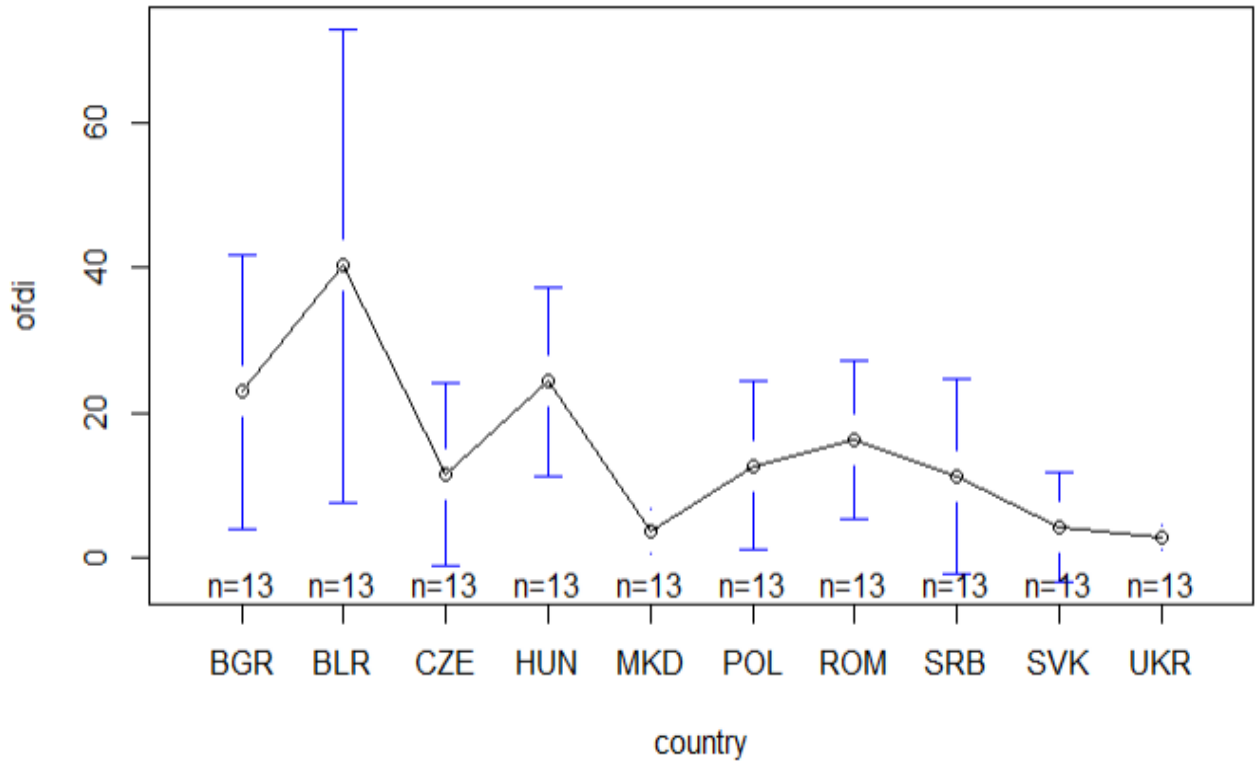

Source: authors' own elaboration

After testing several competing models, we decided to use the one whose results combine a reasonable trade-off between interpretability and model robustness. The fixed effect estimation is presented below. The estimation output reveals that the most important drivers in the model are the EU dummy variable, the openness of the economy to international trade, and the country's competitiveness. The unobserved heterogeneity can be ascribed to the effect of a country group that was not tested explicitly. With the unobserved heterogeneity, the OLS estimates would be both biased and inconsistent. Hence, the estimator used in our case is the Fixed Effects model, which enables us to circumvent the issue of unobserved heterogeneity. Given that the countries in the chosen sample come from the same region (CEE), the fixed effects estimator appears suitable, and no additional subgrouping of the sample is necessary.

The table below summarises the estimation results for the Fixed Effect model set-up. In the final model set-up, we decided against the fdOREMETAL (i.e. the ratio of ore and metal exports to merchandise exports of the host country) variable due to a higher number of data gaps as well as overall questionable data quality in this case. 
Table 4 | Fixed effects model estimation output

\begin{tabular}{|c|c|c|c|c|c|c|}
\hline Fixed Effects & Model 1 & Model 2 & Model 3 & Model 4 & Model 5 & Model 6 \\
\hline G_GDP & $\begin{array}{l}0.021 \\
(0.038)\end{array}$ & $\begin{array}{l}0.202 \\
(0.038)\end{array}$ & $\begin{array}{l}0.200 \\
(0.039)\end{array}$ & $\begin{array}{l}0.021 \\
(0.038)\end{array}$ & $\begin{array}{l}0.027 \\
(0.039)\end{array}$ & $\begin{array}{l}0.235 \\
(0.038)\end{array}$ \\
\hline EU_DUMMY & $\begin{array}{l}2.010^{*} \\
(1.159)\end{array}$ & $\begin{array}{l}1.131^{*} \\
(1.075)\end{array}$ & $\begin{array}{l}2.030^{*} \\
(1.154)\end{array}$ & $\begin{array}{l}1.013 \\
(1.049)\end{array}$ & $\begin{array}{l}2.010^{*} \\
(1.141)\end{array}$ & $\begin{array}{l}1.021^{*} \\
(1.041)\end{array}$ \\
\hline D_LOG_LWAGE & $\begin{array}{l}-0.102 \\
(0.575)\end{array}$ & $\begin{array}{l}-0.091 \\
(0.573)\end{array}$ & $\begin{array}{l}0.051 \\
(0.573)\end{array}$ & & & \\
\hline TRADE & $\begin{array}{l}1.016^{*} \\
(0.047)\end{array}$ & $\begin{array}{l}2.185 \\
(0.117)\end{array}$ & $\begin{array}{l}1.139^{*} \\
(0.091)\end{array}$ & & & \\
\hline PRIVATfd & $\begin{array}{l}7.354^{\star} \\
(3.702)\end{array}$ & & & & & \\
\hline RDfd & $\begin{array}{l}1.585^{\star} \\
(1.028)\end{array}$ & & & & $\begin{array}{l}1.313^{*} \\
(1.055)\end{array}$ & \\
\hline ENTRESTRUCTfd & & $\begin{array}{l}1.005 \\
(1.889)\end{array}$ & & & & $\begin{array}{l}0.813 \\
(1.154)\end{array}$ \\
\hline COMPETfd & $\begin{array}{l}-2.821^{* *} \\
(1.025)\end{array}$ & & $\begin{array}{l}-1.957^{* *} \\
(1.125)\end{array}$ & & & \\
\hline POLITICS & & & & $\begin{array}{l}0.282 \\
(0.358)\end{array}$ & & \\
\hline CPIfd & & $\begin{array}{l}-0.213^{*} \\
(0.052)\end{array}$ & & & $\begin{array}{l}-0.118^{*} \\
(0.064)\end{array}$ & \\
\hline R-sq. within & 0.182 & 0.122 & 0.105 & 0.108 & 0.146 & 0.125 \\
\hline R-sq. between & 0.256 & 0.231 & 0.202 & 0.207 & 0.213 & 0.231 \\
\hline F-test (model) & 1.212 & 1.098 & 1.093 & 1.095 & 1.186 & 1.174 \\
\hline SD (dep. var.) & 0.107 & 0.107 & 0.107 & 0.107 & 0.107 & 0.107 \\
\hline Obs. & 139 & 139 & 139 & 139 & 139 & 139 \\
\hline
\end{tabular}

Note: Asterisks ${ }^{* * *},{ }^{* *},{ }^{*}$ indicate significance at the $1 \%, 5 \%$, and $10 \%$ significance levels, respectively.

Source: authors' own calculations

Interestingly, as can be observed, most macroeconomic variables do not play any substantive role in driving China's direct investment in the CEE region, with the notable exception of trade openness. For the latter, the results indicate that a $1 \%$ increase in trade openness in period $t-1$ leads to approximately a $1 \%$ increase in Chinese ODI in period $t$ as both variables are expressed in elasticities. Instead, the dummy variable for EU membership appears to be significant in all model set-ups, with the positive impact of being the member state ranging from 100 to $200 \%$ compared to the situation of being outside of this community. Meanwhile, 
from the structural and regulatory indicators, both the corruption perception index as well as competition policy index show significance, too, but with negative signs, hinting that Chinese ODI seeks looser market conditions in the destination country. Looking at the coefficients, we can estimate that increasing corruption perception index decelerates growth in FDI by up to $20 \%$, while stricter competition policy leads to an outright decrease in FDI as the coefficients reach values of more than one in both cases. Finally, the R\&D variable is also somewhat significant in both model set-ups, supporting the argument that Chinese FDI might seek access to new technologies and practices. The other variables are not significant or nearly irrelevant and even worsen the model performance.

\section{Conclusion}

Following the recent rapid economic growth, China became the third-largest exporter of ODI escaping, thereby classical evolution of a developing country. China, though facing multiple problems connected to its liability of foreignness, possesses some specifics that are beneficial to it when investing abroad. The biggest one of them is probably an immense help from the Chinese government, especially in providing state-owned MNEs with cheap capital that is generated mostly by China's huge foreign exchange reserves (Konzett et al., 2015).

As for Central and Eastern Europe, China started to invest in this market relatively recently, and albeit CEEC are not of China's biggest interest, the ODI is flowing in those countries in greater numbers every year.

The literature emerged in the field of Chinese ODI, yet the motivations behind its investments are not quite clear, and that is especially true in the case of CEEC as this part of the world is rather forgotten by the economic research. This thesis analyses macroeconomic data about Chinese ODI flow in CEEC through a linear regression model integrating three different theoretical arguments: first, through the lens of OLI framework, three main motivations of ODI are studied, which are market-seeking, resource-seeking and efficiency-seeking; second, the institutional framework is incorporated in the model as institutions undoubtedly play an important role in attracting or repelling the inflow of foreign investment; and third, also the Chinese liability of foreignness is added in as it may constitute an important determinant of ODI.

The dataset used in this thesis forms unbalanced panel data containing ODI flows from China to eight CEE countries from 2005 to 2018, and the data are obtained from the UNCTAD database. However, there are few limitations to these data, especially the underestimation of ODI flows caused by offshoring through tax heavens as they grant a lot of financial benefits to the investing firms.

The findings show that the market-seeking motivation of Chinese ODI in the case of CEEC is not entirely confirmed. Still, accession to the EU as a dummy variable is found statistically significant throughout the whole modelling, implying thereby at least some importance of belonging to the EU when attracting foreign Chinese investment. Being a part of the EU also means being a part of its internal common market, which means that by accessing one member state, the whole EU market is accessed too, and for China, who considers Eastern Europe as a 'backdoor' to the EU (Éltetö \& Szunomár, 2016), this fact must be crucial.

The only exogenous variable serving as a proxy for Chinese 'liability for foreignness', the dummy variable for pro-American countries, is found insignificant and having a positive sign, 
which points to the fact that when it comes to business politics goes aside in the case of China. But such a conclusion is, of course, highly speculative. The countries with a negative attitude to the US include Bulgaria, Ukraine, Belarus, and Slovakia, while this was recorded during at least some part of the covered time span. For instance, the change from having a negative attitude to the US to the positive occurred in Ukraine in 2014 following the regime shift.

Clearly, limitations exist. The major pitfall of our research is connected to data quality. Chinese ODI are still not that well monitored, and putting aside the problem of offshoring, a lot of data is missing or is incomplete in the case of CEEC, which caused the reduction of the studied sample only to eight countries. What is proposed for future research in this field and what was also recommended by other scholars like Sutherland and Anderson (2015) is to use commercial databases about Chinese ODI instead of macroeconomic foreign investment data collected by governments. Such databases as Zephyr database collecting information about cross-border M\&A or Financial markets database collecting all Gls, data provide much more precise information as they track the whole investment process, from the initial enterprise to the final one.

Another limitation of this thesis is the selection of a correct variable representing Chinese liability of foreignness. What proxy other than Chinese diaspora relates the best to the Chinese speciality of social networking or so-called 'guanxi'? Or another question, also posed by Deng (2013) when reviewing existing research about Chinese ODI, is what proxy deals the best with the Chinese political environment particularity in connection with the fact that many of its MNEs are SOEs relying on government-to-government relations? It is the challenge of further research to examine this area of Chinese ODI flows to foreign countries and to the CEEC region.

\section{Acknowledgement}

A part of the article has already been published in a diploma thesis called 'Key Determinants of Chinese Direct Investment in Central and Eastern Europe', defended at the University of Economics in Prague in 2016. In comparison with the previous version, the current text contains a number of changes, updates and significant extensions.

No potential conflict of interest was reported by the authors.

\section{References}

Amighini, A., Cozza, C., Rabellotti, R., \& Sanfilippo, M. (2014). Investigating Chinese outward foreign direct investments: How can firm-level data help? China and World Economy, 22(6), 44-63. https://doi.org/10.1111/cwe.12091.

Botrić, V., \& Škuflić, L. (2006). Main determinants of foreign direct investment in the south east European countries. Transition Studies Review, 13(2), 359--377. https://doi.org/10.1007/s11300-006-0110-3.

Bruce-Lockhart, A. (2017). China's $\$ 900$ billion New Silk Road. What you need to know. World Economic Forum. https://www.econstor.eu/bitstream/10419/17819/1/kap1143.pdf

Buckley, P. J., Clegg, L. J., Cross, R. A., Liu, X., Voss, H., \& Zheng, P. (2007). The determinants of Chinese outward foreign direct investment. Journal of International Business Studies, 38(4), 499-518. https://doi.org/10.1057/palgrave.jibs.8400277. 
Carstensen, K., \& Toubal, F. (2003). Foreign Direct Investment in Central and Eastern European Countries: A Dynamic Panel Analysis. Kiel Institute for World Economics. https://www.econstor.eu/bitstream/10419/17819/1/kap1143.pdf

Chen, W., \& Tang, H. (2014). The dragon is flying West: micro-level evidence of Chinese outward direct investment. Asian Development Review, 31(2), 109-140. https://doi.org/10.1162/ADEV_a_00032.

Cheung, Y. W., \& Qian, X. (2009). Empirics of China's outward direct investment. Pacific Economic Review, 14(3), 312-341. https://doi.org/10.1111/j.1468- 0106.2009.00451.x.

Deng, P. (2013). Chinese outward direct investment research: Theoretical integration and recommendations. Management \& Organization Review, 9(3), 513-539. https://doi.org/10.1111/more.12030.

Donu, V., \& Janíčko, M. (2018). Do institutions still matter for investors? Impact of institutional determinants on investment inflows into European economies. Acta Oeconomica, 68(2), 245-270. https://doi.org/10.1556/032.2018.68.2.4.

Du, J., \& Zhang, Y. (2018). Does One Belt One Road initiative promote Chinese overseas direct investment? China Economic Review, 47(C), 189-205. https://doi.org/10.1016/j.chieco.2017.05.010.

Dunning, J. H., \& Narula, R. (2003). Foreign direct investment and governments: Catalysts for economic restructuring. New York, NY: Routledge.

Dunning, J. H., \& Lundan, S. M. (2008). Institutions and the OLI paradigm of the multinational enterprise. Asia Pacific Journal of Management, 25(4), 573-593. https://doi.org/10.1007/s10490-007-9074-z.

Éltetö, A., \& Szunomár, A. (2016). Chinese investment and trade - Strengthening ties with Central and Eastern Europe. International Journal of Business and Management, 4(1), 24-48. https://doi.org/10.20472/BM.2016.4.1.002.

Garcia-Herrero, A., Xia, L., \& Casanova, C. (2015). Chinese Outbound Foreign Direct Investment: How Much Goes Where after Roundtripping and Offshoring? SSRN Electronic Journal. https://doi.org/10.2139/ssrn.3160534.

Gouel, C., Houssein, G., \& Laborde, D. (2012). A Foreign Direct Investment Database for Global CGE Models. CEPII Centre d'études prospectives et d'informations internationales, http://www.cepii.fr/PDF_PUB/wp/2012/wp2012-08.pdf.

Goh, B. (2015). China Railway Group Team Wins \$1.6 BIn Hungary High-Speed Rail Contract. Reuters, November 2015. http://in.reuters.com/article/china-hungaryrailway-idINL8N13K1YF20151125.

Hong, E., \& Sun, L. (2006). Dynamics of internationalization and outward investment: Chinese corporations' strategies. The China Quarterly, 187(3), 610-634. https://doi.org/10.1017/S0305741006000403.

Huang, Y., \& Wang, B. (2013). Investing overseas without moving factories abroad: The case of Chinese outward direct investment. Asian Development Review, 30(1), 85-107. https://doi.org/10.2139/ssrn.2260029.

Kersan-Škabić, I. (2013). Institutional development as a determinant of FDI attractiveness in Southeast Europe. Društvena Istraživanja / Journal for General Social Issues, 22(2), 215-235. https://doi.org/10.5559/di.22.2.01. 
Kolstad, I., \& Wiig, A. (2012). What determines chinese outward FDI? Journal of World Business, Focus on China Special Section, 47(1), 26-34. https://doi.org/10.1016/j.jwb.2010.10.017.

Konzett, E., Miljkovic, M., \& Kühnlenz, A. (2015). Chinesische Investitionen in Osteuropa. WirtschaftsBlatt Medien $\mathrm{GmbH}$.

Korniyenko, Y., \& Sakatsume, T. (2009). Chinese Investment in the Transition Countries. European Bank for Reconstruction and Development. http://www.ebrd.com/downloads/research/economics/workingpapers/wp0107.pdf

Li, C., Liu, H., \& Jiang, Y. (2015). Exchange rate risk, political environment and Chinese outward FDI in emerging economies: A panel data analysis. Economics World, 3(5-6), 145-155. https://doi.org/10.17265/2328-7144/2015.0506.004.

Lu, J., Liu, X., \& Hongling, W. (2011). Motives for outward FDI of Chinese private firms: Firm resources, industry dynamics, and government policies. Management and Organization Review, 7(2), 223-248. https://doi.org/10.1111/j.1740-8784.2010.00184.x.

MOFCOM. (2015). Catalogue for the Guidance of Foreign Investment Industries. http://www.fdi.gov.cn/1800000121_39_4830_0_7.html.

OECD. (2008). OECD Benchmark Definition of Foreign Direct Investment, Fourth Edition. OECD Publishing, http://www.oecd.org/daf/inv/investmentstatisticsandanalysis/40193734.pdf

Ross, J. (2016). China Strengthening Links with Eastern Europe. http://www.china.org.cn/opinion/201605/17/content_38470993.htm.

Sutherland, D., \& Anderson, J. (2015). The pitfalls of using foreign direct investment data to measure Chinese multinational enterprise activity. The China Quarterly, 221(1), 21-48. https://doi.org/10.1017/S0305741014001490.

Tianping, K. (2015). The 16+1 Framework and Economic Relations Between China and the Central and Eastern European Countries. Council for European Studies, December 2015.

UNCTAD. (2019). World Investment Report 2019, https://unctad.org/webflyer/world-investment-report2019.

Voss, H., Buckley, P. J., \& Cross, A. R. (2010). The impact of home country institutional effects on the internationalization strategy of Chinese firms. Multinational Business Review, 18(3), 25-48. https://doi.org/10.1108/1525383X201000014.

Wang, C., Hong, J., Kafouros, M., \& Boateng, A. (2012). What drives outward FDI of Chinese firms? Testing the explanatory power of three theoretical frameworks. International Business Review, 21(3), 425-438.

Wang, Y., Du, J., \& Wang, K. (2015). The determinants of location choices of China's ODI: Institutions, taxation and resources. Frontiers of Economics in China, 10(3), 540-565. https://doi.org/10.3868/s060004-015-0024-6.

The research paper passed the review process. | Received: June 9, 2020; Revised: August 9, 2020; Accepted: August 10, 2020; Pre-published online: January 29, 2021; Published in the regular issue: July 2, 2021. 